\title{
Socio-Economic Factors Affecting Home Internet Usage Patterns in Central Queensland
}

\author{
W. J. Taylor, G. Zhu, J. Dekkers and S. Marshall \\ Central Queensland University, Rockhampton QId 4700, Australia
}

\author{
w.taylor@cqu.edu.au g.zhu@cqu.edu.au j.dekkers@cqu.edu.au \\ s.marshall@cqu.edu.au
}

\begin{abstract}
This paper aims to identify associations between demographic and socioeconomic factors and home Internet use patterns in the Central Queensland region, Australia. It found that people living outside of Rockhampton, male, those with higher education levels, married, those with higher income level, or fully employed tend to use Internet more for work at home; people living in Rockhampton, those within the youngest group (18-24), or with secondary education level or higher tend to use Internet more for education; people living in Rockhampton, those within the youngest group, never married, or une mployed tend to use Internet more for entertainment; males, people within the youngest group, those with lower family income, or either semi-employed or unemployed tend to use Internet more for information search; females, people with no children, or lower family income tend to use Internet more for communication through email; married people tend to use Internet for financial management; and people within 25-39 year old group, with higher education levels tend to use Internet more for on-line purchases. It is suggested that further research should be conducted to monitor the youngest age group in home Internet use for entertainment and information search.
\end{abstract}

Keywords : Community Informatics, demographic and socio-economic factors, Internet usage patterns, Central Queensland, consumer ICT behaviors, community informatics systems.

\section{Introduction}

Regional Information Communications Technology (ICT) infrastructure projects funded by the Australian Government determined that a priority needed to be given to rural and regional areas so that they have the same opportunities from the information economy as capital cities and metropolitan areas (NOIE, 2002). The use of ICT in regional, rural and remote areas has been increasingly promoted in Australia over the past 5 years in order to provide cheaper and more efficient Internet and e-mail access for people living in these areas (Chenoweth \& Stehlik 2002). However, although the Central Queensland (CQ) region which is situated on the coast in the north-eastern part of Australia straddling the Tropic of Capricorn covering some 250,000 square kilometres and has a population of approximately 300,000 has had reasonable and growing access to ICT infrastructure over recent years, the home adoption of Internet has been lower than the national average (Taylor, 2002). Demographic and socio economic factors (location, gender, age, education levels, martial status, children at home, dwelling ownership, combined

Material published as part of these proceedings, either on-line or in print, is copyrighted by Informing Science. Permission to make digital or paper copy of part or all of these works for personal or classroom use is granted without fee provided that the copies are not made or distributed for profit or commercial advantage AND that copies 1) bear this notice in full and 2) give the full citation on the first page. It is permissible to abstract these works so long as credit is given. To copy in all other cases or to republish or to post on a server or to redistribute to lists requires specific permission from the publisher at Publisher@InformingScience.org family income and employment status) affecting Internet access from home CQ have been analysed and reported (Taylor et al. 2002).

Content and service providers now use the World Wide Web (WWW) to provide modern consumers with a wealth of information, entertainment and commerce opportunit ies at home (Stafford 2002). However, in order to better understand 
why home Internet usage in regional areas remains relatively lower than capital cities despite reasonable access to ICT infrastructure, consumers' behaviour in the home use of the Internet needs to be studied. These behaviours can be categorized as: work at home, education, entertainment, information search, email, managing home finance, on-line purchase and community networking. Following a review of the literature, this research hypothosises that there are differences in Internet usage patterns between young and old, male and female, people in urban and rural areas, married and unmarried, well-educated and less educated, rich and poor, and employed and une mployed. This paper examines differences in home Internet use across these parameters and the associations between home Internet consumption patterns and demographic and socio-economic factors in CQ. It also provides relevant information for sociologists, psychologists and other profe ssionals who are involved in examining social uses in the adoption of ICT in regional areas generally and in Australia, in particular.

The instrument used to collect the data for the paper was the Central Queensland Social Survey (CQSS), which was jointly conducted by the Centre for Social Science Research (Mummery and Schofield 2001) and Community Informatics (COIN) Internet Academy, Central Queensland University.

\section{Methodology}

\section{Data Collection}

The 2001 CQSS$^{1}$ was administrated through the CATI (Computer-assisted Telephone Interviewing) system at the Population Research Laboratory within the Centre for Social Science Research at CQU (Mummery and Schofield 2001).

The interviews were conducted from $9^{\text {th }}$ to the $25^{\text {th }}$ November, 2001. The CATI program allowed the sample to reflect the socio economic profile of the region by identifying and managing the proportions of socio economic subsets required. In all 1200 interviews were collected with 400 being from Rockhampton and the remainder collected from within a $350 \mathrm{~km}$ radius of Rockhampton.

Full details and purposes of interview were reported by Taylor (2002). One of the purposes was to identify Internet usage patterns and their associations with demographic and socio economic parameters in CQ. Eight Internet usage patterns and nine parameters are abstracted in Fig 1.

\section{Data Analysis}

Chi-square tests were employed to examine significant difference between two and three categories within a variable, and associations between pairs of variables (after Kinnear and Gray 1997). Significant difference level was set at $\mathrm{p}=0.05$, but when $0.1<\mathrm{P}>0.5$, the associations between two variables are also discussed. However, using these methods for variables with more than two levels creates difficulties in identifying which category of a variable is significantly in association with other variables. In addition, one factor may affect Internet connection for different usages. Therefore, multivariate analyses with Post Hoc Tests were also used to obtain the indicative differences between the categories of a variable in association with different Internet usages.

Binary Logistic Regression with categorical covariates was applied to identify factors contributing to each of Internet usages. Odds Ratios (OR) (after Knoke and Bohrnstedt 1994) were used to measure the weight of associations of each factor with each of Internet usages. An OR value of 1.00 indicates that two variables were unrelated; an $\mathrm{OR}>1.00$, indicates the positive co variation of the variables (eg, locations and Internet connection for work at home); an $\mathrm{OR}<1.00$, it indicated negative or inverse co variation. As the covariates (factors) are categorical, the first category of each factor was used as a reference

\footnotetext{
1 Funding to undertake this data collection and analysis was provided by Telstra Research Laboratories, Australia
} 


\begin{tabular}{|l|l|}
\hline Use patterns \\
at home?
\end{tabular}

Figure 1

Outline of question flowchart of

$(\mathrm{OR}=1.00)$ to detect the association of category variation (eg, from younger to older age groups) with each of the Internet use categories.

\section{Results and Discussions}

\section{General Use Patterns}

There was a general tendency for people surveyed across CQ to use Internet at home mainly for communication purposes through email and for information search. This dominant use pattern was followed by uses for entertainment, education, and then work at home. The usage levels for financial management and on-line purchasing were still relatively low, and in this region, the home use of the Internet

\begin{tabular}{|lcc|}
\hline Table 1 & General usage patters for home Internet use $(\mathbf{N}=\mathbf{5 1 2})$ & \\
\hline Use patters & \% of total & Total $\mathbf{~}$ \\
\hline Work at home & 48.5 & 248 \\
Education & 60.1 & 308 \\
Entertainment & 61.0 & 312 \\
Information search & 89.3 & 457 \\
Finance management & 34.7 & 177 \\
Community networking & 8.3 & 42 \\
Email & 89.5 & 459 \\
On-line purchase & 31.6 & 162 \\
\hline
\end{tabular}


was used least for community networking (Table 1).

\section{Specific Usage Patterns according to Demographic and Socioeconomic Pa- rameters}

\section{Location}

The home Internet users in Rockhampton tended to have lower use patterns for working at home, but a higher use patterns for education and entertainment purposes, when compared to their counterparts outside of Rockhampton. The higher use of the Internet for working at home in the areas outside Rockhampton may be explained by the higher proportion of home based businesses including farming in these areas (Tables 2 and 3).

Table 3 The effect of location on home Internet use.

\begin{tabular}{lcccc}
\hline Location & $\begin{array}{c}\text { Work at } \\
\text { home }\end{array}$ & Education & Entertainment & Total \\
\hline Rockhampton & 43.8 & 69.5 & 68.9 & 177 \\
$\begin{array}{l}\text { Reminder of the } \\
\text { region }\end{array}$ & 51.0 & 55.2 & 56.9 & 335 \\
Total & 48.5 & 60.2 & 61.1 & 512 \\
\hline $\mathrm{P}$ & 0.070 & 0.002 & 0.005 & \\
\hline
\end{tabular}

Table 3 The effect of gender on home Internet use

\begin{tabular}{lcccc}
\hline Gender & Work at home & $\begin{array}{c}\text { Information } \\
\text { search }\end{array}$ & Email use & Total \\
\hline Male & 51.5 & 92.5 & 87.2 & 266 \\
Female & 45.1 & 86.5 & 92.2 & 245 \\
Total & 48.4 & 89.6 & 89.6 & 511 \\
\hline P & 0.087 & 0.027 & 0.042 & \\
\hline
\end{tabular}

\section{Age}

Table 4 presents the effects of age group on home Internet use. Home Internet use for information search was high across all age cohorts except for the senior cohort $(>55)$.

HomeInternet use in the 25-39 age cohort was dominant for education, entertainment, information search, managing home finances and on-line purchasing. The youngest age cohort (18-24) also had high use for education; entertainment and information search but were relatively low users for managing home finances and on-line purchasing. 
Table 4 The effect of age home Internet use.

\begin{tabular}{lllllll}
\hline $\begin{array}{l}\text { Age } \\
\text { group }\end{array}$ & Education & Entertainment & $\begin{array}{l}\text { Information } \\
\text { search }\end{array}$ & $\begin{array}{l}\text { Managing } \\
\text { home fi- } \\
\text { nance }\end{array}$ & $\begin{array}{l}\text { On-line } \\
\text { pur- } \\
\text { chase }\end{array}$ & Total \\
\hline $18-24$ & $75.0 \mathbf{a}^{*}$ & $83.3 \mathbf{a}$ & $95.8 \mathbf{a}$ & $16.7 \mathbf{b}$ & $16.7 \mathbf{b}$ & 48 \\
$25-39$ & $67.0 \mathbf{a}$ & $70.7 \mathbf{a}$ & $92.6 \mathbf{a}$ & $39.3 \mathbf{a}$ & $40.3 \mathbf{a}$ & 191 \\
$40-55$ & $57.0 \mathbf{b}$ & $54.9 \mathbf{b}$ & $89.8 \mathbf{a}$ & $36.2 \mathbf{a}$ & $30.0 \mathbf{b}$ & 207 \\
$>55$ & $37.5 \mathbf{c}$ & $34.4 \mathbf{c}$ & $75.0 \mathbf{b}$ & $29.7 \mathbf{a b}$ & $23.4 \mathbf{b}$ & 64 \\
Total & 60.0 & 60.9 & 89.6 & 34.7 & 31.8 & 510 \\
\hline P & $<0.0001$ & $<0.0001$ & $<0.0001$ & 0.023 & 0.003 \\
\hline * percentages denoted with different characters indicate significant differences a $<<0.05$
\end{tabular}

The lower proportion in use Internet for managing home finance and on-line purchase of youngest age group may imply that the majority of this group was either not financially independent, did not have substantial financial issues of debt or investment or did not rate budgeting highly.

It is clear that the senior age cohort (>55) generally lagged behind other groups for all aspects of Internet usage.

\section{Education levels}

People with higher education levels tended to have higher home Internet use for work at home, education, information search, and on-line purchasing, when compared to those with lower education levels (Table 5). These differences indicated that people with higher education levels may have jobs which make use of computers in the workplace thus increasing their application knowledge, skill levels and

Table 5 The effects of education on home Internet use

\begin{tabular}{llllll}
\hline $\begin{array}{l}\text { Education } \\
\text { levels }\end{array}$ & $\begin{array}{l}\text { Work at } \\
\text { home }\end{array}$ & Education & $\begin{array}{l}\text { Information } \\
\text { search }\end{array}$ & $\begin{array}{l}\text { On-line } \\
\text { purchase }\end{array}$ & Total \\
\hline Primary\# & $28.6 \mathbf{b}^{*}$ & $28.6 \mathbf{b}$ & $71.4 \mathbf{b c}$ & $14.2 \mathbf{a b}$ & 7 \\
Secondary & $38.4 \mathbf{b}$ & $55.4 \mathbf{b}$ & $89.8 \mathbf{a b}$ & $22.0 \mathbf{b}$ & 186 \\
TAFE & $40.2 \mathbf{b}$ & $58.3 \mathbf{a b}$ & $85.8 \mathbf{c}$ & $33.9 \mathbf{a}$ & 127 \\
University & $64.4 \mathbf{a}$ & $67.0 \mathbf{a}$ & $92.6 \mathbf{a}$ & $40.3 \mathbf{a}$ & 191 \\
Total & 48.4 & 60.1 & 89.6 & 31.7 & 511 \\
\hline P & $<0.0001$ & 0.035 & 0.010 & 0.001 & \\
\hline
\end{tabular}

\#Significant differences were automatically justified due to small number of samples

* percentages denoted with different characters indicate significant differences a $\mathrm{p}<0.05$

computer-skills support networks. Further, some of these types of jobs require regular extended work hours to achieve agreed performance targets. Other work has found that professional workers show a preference for working the extended hours at home close to family in preference to work at the work place (Taylor, 2002). However, it must be noted that due to low representation in the primary education level, the significant differences were automatically justified when conducting statistical tests. 


\section{Marital status}

In this survey, the never married people had higher home Internet use for working at home, education, entertainment, and email, but lower use for managing home finances when compared to people with other marital states (Table 6). There was a higher proportion of never married people in the younger age groups and it is understandable that people in these groups' such students, may have more spare time to use the Internet for education, entertainment, and use email to communicate with their friends. This analysis again points to the non- use of home Internet for managing home finances by younger and single people. However, it is hard to explain why people never married had higher home use of the Internet for work at home. Possible explanations lie in the area of increased available time when compared to people with partners and families.

It seems logical that married people tend to use the Internet to work at home and managing home finances. As indicated above and in other work (Taylor, 2002) people with partners and families show a preference for this method of balancing their work and domestic goals. It is proposed that married people are more likely to have and recognise needs for close management of home finances

Table 6 The effects of marital status on home Internet usage patterns.

\begin{tabular}{lllllll}
\hline Marital status & $\begin{array}{l}\text { Work at } \\
\text { home }\end{array}$ & Education & Entertainment & Email use & $\begin{array}{l}\text { Managing } \\
\text { home finance }\end{array}$ & $\begin{array}{l}\text { Total } \\
\mathbf{N}\end{array}$ \\
\hline Never married & $54.4 \mathbf{a}^{*}$ & $69.9 \mathbf{a}$ & $78.6 \mathbf{a}$ & $97.1 \mathbf{a}$ & $21.4 \mathbf{b}$ & 103 \\
Used-to-be & $26.2 \mathbf{b}$ & $66.7 \mathbf{b}$ & $59.5 \mathbf{b}$ & $83.3 \mathbf{b}$ & $21.4 \mathbf{b}$ & 42 \\
married & & & & & & \\
Married & $49.5 \mathbf{a}$ & $56.7 \mathbf{b}$ & $56.3 \mathbf{b}$ & $88.3 \mathbf{b}$ & $39.8 \mathbf{a}$ & 367 \\
Total & 48.5 & 60.2 & 61.1 & 89.6 & 34.6 & 511 \\
\hline P & 0.007 & 0.035 & $<0.0001$ & 0.013 & $<0.0001$ & \\
* percentages denoted with different characters indicate significant differences a p<0.05
\end{tabular}

\section{Children at home}

People with children at home used the Internet more for education, information, and managing their home finance, but less for email use, when compared to those without children (Table 7).

It is proposed that those with children at home and the children themselves may have a higher immediate need to use Internet for on- line education and information search, and those without children (including never married and used-to-be married persons) may have more free time to communicate with friends through email.

Table $7 \quad$ Effect of children at home on home Internet use

\begin{tabular}{llllll}
\hline Children at home & Education & $\begin{array}{l}\text { Information } \\
\text { search }\end{array}$ & Email use & $\begin{array}{l}\text { Managing } \\
\text { home finance }\end{array}$ & Total N \\
\hline $\begin{array}{l}\text { No children } \\
\begin{array}{l}\text { At least one } \\
\text { child }\end{array}\end{array}$ & 54.9 & 87.3 & 93.2 & 30.8 & 237 \\
Total & 64.7 & 91.6 & 86.5 & 37.8 & 275 \\
$\mathrm{P}$ & 60.2 & 89.6 & 89.6 & 34.6 & 512 \\
\hline
\end{tabular}




\section{Dwelling ownership}

People who rent residential properties tended to have higher home Internet usage patterns for entertainment and information searching, but lower usage for managing home finances, when compared to those who owned their own properties (Table 8).

As evident in the data presented in Table 9, people who rented properties were mainly within younger age groups (18-24, 25-39). Renting usually indicates lowered capital reserves and less emphasis on delayed gratification capital expenditure. The home Internet consumption patterns of younger age groups as presented in Table 4, support a proposition of lower use for managing home finances in this group.

Table 9 The effect of dwelling ownership on home Internet use

\begin{tabular}{lllll}
\hline Dwelling ownership & Entertainment & Information search & $\begin{array}{l}\text { Managing fi- } \\
\text { nance }\end{array}$ & Total N \\
\hline Rent & 70.1 & 93.5 & 25.2 & 107 \\
Own house/flat & 58.2 & 88.1 & 37.7 & 378 \\
Total & 60.8 & 89.3 & 35.0 & 485 \\
\hline P & 0.026 & 0.074 & 0.017 & \\
\hline
\end{tabular}

Table 9 Rent associated with age groups

\begin{tabular}{cccccc}
\hline Age group & $\begin{array}{c}\text { Within } \\
\text { group }(\%) \#\end{array}$ & $\mathrm{~N}$ & $\begin{array}{c}\text { Across groups } \\
(\%)\end{array}$ & $\begin{array}{c}\text { Total no of the } \\
\text { group }\end{array}$ & $\mathrm{p}$ \\
\hline $18-24$ & 70.3 & 52 & 19.0 & 74 & $<0.0001$ \\
$25-39$ & 34.5 & 115 & 42.0 & 333 & \\
$40-55$ & 16.2 & 71 & 25.9 & 437 & \\
$>55$ & 11.7 & 36 & 13.1 & 309 & \\
Total & 23.8 & 274 & 100.0 & 1153 & \\
\hline
\end{tabular}

\section{Combined family income per week}

The middle range income group (AUD \$160 - \$399 per week) had the lowest home Internet use for work at home, entertainment, information search and email use, when compared to the other two income groups. Both the highest and the lowest income groups had similar trends of Internet usage patterns

Table 10 The effect of combined family income per week on home Internet usage patterns

\begin{tabular}{lllllll}
\hline $\begin{array}{l}\text { Combined household } \\
\text { income pw AUD\$ }\end{array}$ & $\begin{array}{l}\text { Work } \\
\text { at } \\
\text { home }\end{array}$ & Education & Entertainment & $\begin{array}{l}\text { Information } \\
\text { search }\end{array}$ & $\begin{array}{l}\text { Email } \\
\text { use }\end{array}$ & $\begin{array}{l}\text { Total } \\
\text { N }\end{array}$ \\
\hline$<160$ & $54.3 \mathbf{a}^{*}$ & $52.9 \mathbf{b}$ & $60.1 \mathbf{a}$ & $91.3 \mathbf{a}$ & $92.5 \mathbf{a}$ & 173 \\
$160-399$ & $28.6 \mathbf{b}$ & $57.1 \mathbf{b}$ & $38.1 \mathbf{b}$ & $71.4 \mathbf{b}$ & $76.2 \mathbf{b}$ & 21 \\
$>400$ & $46.7 \mathbf{a}$ & $64.4 \mathbf{a}$ & $63.1 \mathbf{a}$ & $89.9 \mathbf{a}$ & $89.0 \mathbf{a}$ & 317 \\
Total & 48.5 & 60.2 & 61.1 & 89.6 & 89.6 & 511 \\
\hline P & 0.047 & 0.044 & 0.072 & 0.018 & 0.055 & \\
\hline * percentages denoted with different characters indicate significant differences a p<0.05
\end{tabular}


(Table 10).

Further analysis presented in Table 11 indicates that middle range income (AUD \$160 -\$399 per week) was strongly associated with the senior age group $(>55)$. The effect of age on home Internet usage patterns is presented in Table 4.

Table 11 The effect of age the middle range income (AUD \$160-399) group

\begin{tabular}{cccccc}
\hline Age group & $\begin{array}{c}\text { Within the } \\
\text { group (\%) \# }\end{array}$ & $\mathrm{N}$ & $\begin{array}{c}\text { Across groups } \\
(\%)\end{array}$ & $\begin{array}{c}\text { Total no of the } \\
\text { group }\end{array}$ & $\mathrm{p}$ \\
\hline $18-24$ & 8.4 & 8 & 6.3 & 95 & $<0.0001$ \\
$25-39$ & 6.3 & 22 & 17.3 & 347 & \\
$40-55$ & 6.4 & 28 & 22.0 & 439 & \\
$>55$ & 21.8 & 69 & 54.3 & 316 & \\
Total & 10.6 & 127 & 100.0 & 1197 & \\
\hline
\end{tabular}

\section{Employment status}

The effect of employment status on home Internet usage patterns is presented in Tables 12 and 13. Employment status was only significant for home use of the Internet for work at home and entertainment. No differences were detected between fully and semi- employed people regarding the proportion of work at home. However, it is interesting to note that $26.3 \%$ of unemployed people surveyed claimed being working at home. This is probably due to the system error caused by data re-categorisation, as unemployed people were defined to include retired, pension and home duties and some of those may have

Table 12 The effect of employment status on home Internet use

\begin{tabular}{llll}
\hline Employment status & Work at home & Entertainment & Total \\
\hline Fully employed & $58.3 \mathbf{a}$ & $68.7 \mathbf{a}$ & 266 \\
Semi-employed & $48.8 \mathbf{a}$ & $52.8 \mathbf{b}$ & 127 \\
Unemployed & $26.3 \mathbf{b}$ & $52.9 \mathbf{b}$ & 118 \\
Total & 48.5 & 61.1 & 511 \\
\hline $\mathrm{P}$ & $<0.0001$ & 0.001 & \\
\hline * percentages denoted with different characters indicate significant differences a p<0.05
\end{tabular}

part time jobs as well.

The proportions of Internet use for entertainment for semi- and un- employed people were lower than those who were fully employed. The reason for this was that these groups of people were strongly associated with ( $\mathrm{p}<0.0001)$ age groups; at the age of 40 and over, over 55\% are semi-employed and over $75 \%$ are unemployed (Table 13). Age groups associated with the entertainment use was presented in Table 4

The summary of associations between each of the demographic and socio economic factors and Internet usage patterns is presented in Table 14. No association between these factors and community networking was detected and therefore these data are not presented here.

Table 14 demonstrates that each of the individual factors may have multiple Internet usage patterns, and each usage pattern can be affected by multiple factors. In addition, it is obvious that these parameters 
Table 13 The effect of employment status on age

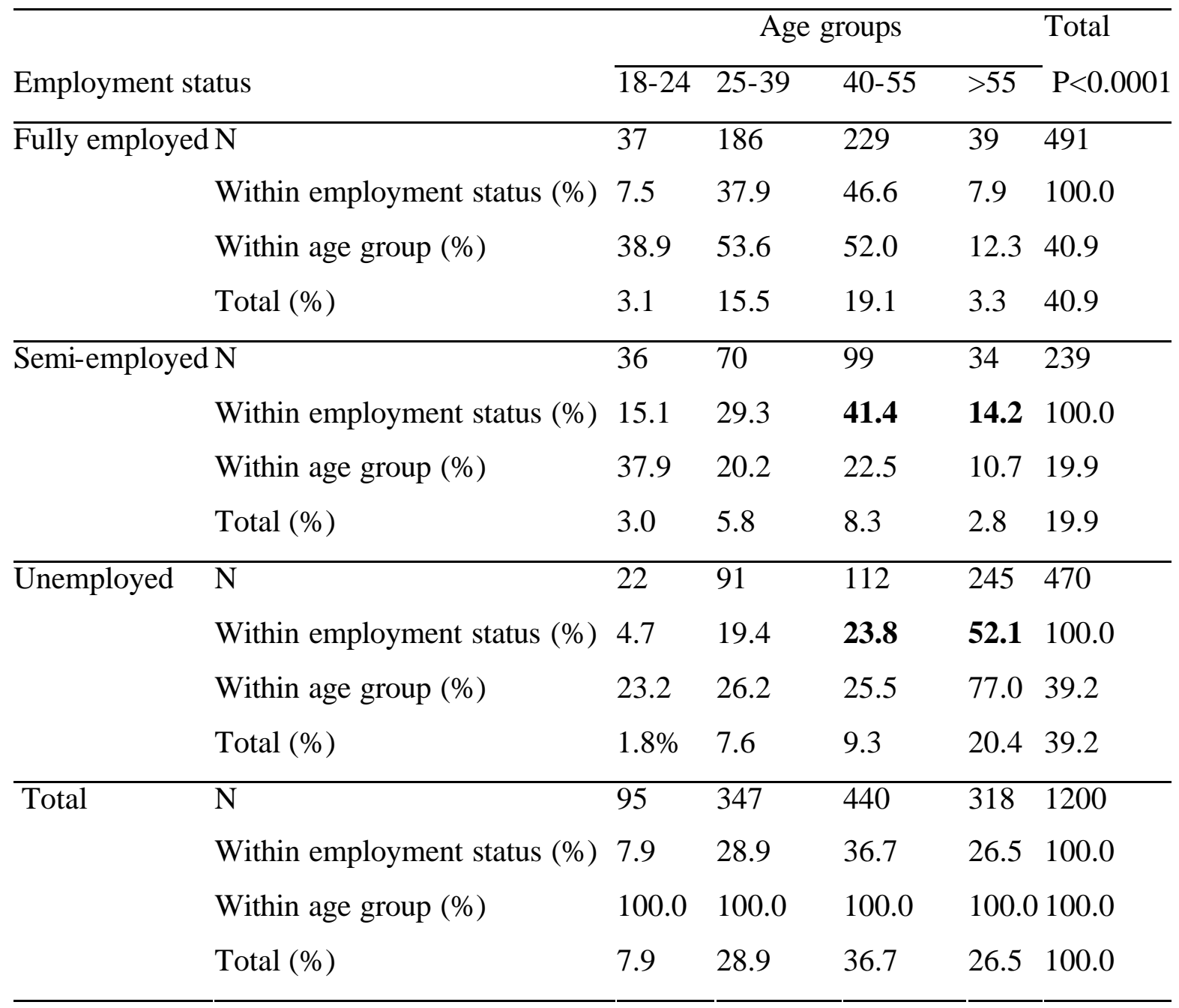

may be also interrelated. In order to examine potential interrelations and to quantify how parameter variations influence usage patterns, logistic regression with odds ratios were undertaken. This data is presented in Table 15.

People living outside of Rockhampton, male, those with higher education levels, married, those with higher income level, or fully employed tended to use Internet more for work at home when compared to each of their counterparts.

People living in Rockhampton, those with youngest group (18-24), or those with secondary education level or higher levels tended to use Internet at home more for education, when compared to each of their counterparts.

People living in Rockhampton, those within the youngest group, never married or unemployed tended to use Internet at home more for entertainment.

Males, those within the youngest group, with lower family income, and either semi-employed or unemployed tended to use Internet at home more for information search.

Female, those with no children, or those with lower family incomes tended to use Internet at home more for communication through email.

Married people used Internet at home more for financial management. 
Table 14 Summarised demographic and socio economic parameters on home Internet usage patterns in CQ (2001)

\begin{tabular}{|c|c|c|c|c|c|c|c|}
\hline & $\begin{array}{l}\text { Work } \\
\text { (1) }\end{array}$ & $\begin{array}{l}\text { Education } \\
\text { (2) }\end{array}$ & $\begin{array}{l}\text { Entertainment } \\
\text { (3) }\end{array}$ & $\begin{array}{l}\text { Information } \\
\text { search } \\
\text { 4) }\end{array}$ & $\begin{array}{l}\text { Email } \\
\text { use } \\
(5)\end{array}$ & $\begin{array}{l}\text { Managing } \\
\text { finance } \\
\text { (6) }\end{array}$ & $\begin{array}{l}\text { On-line } \\
\text { purchas } \\
\text { (7) }\end{array}$ \\
\hline Locations & + & $* *$ & $* *$ & ns & ns & ns & ns \\
\hline Gender & + & ns & ns & $*$ & $*$ & ns & ns \\
\hline Age & ns & $* * *$ & $* * *$ & $* * *$ & ns & $*$ & $* *$ \\
\hline $\begin{array}{l}\text { Education } \\
\text { levels }\end{array}$ & $* * *$ & $*$ & ns & $* *$ & ns & ns & $* *$ \\
\hline $\begin{array}{l}\text { Martial } \\
\text { status }\end{array}$ & $* *$ & $*$ & $* * *$ & ns & $*$ & $* * *$ & ns \\
\hline $\begin{array}{l}\text { Children at } \\
\text { home }\end{array}$ & ns & $*$ & ns & + & $*$ & + & ns \\
\hline $\begin{array}{l}\text { Dwelling } \\
\text { ownership }\end{array}$ & ns & ns & $*$ & + & ns & $*$ & ns \\
\hline $\begin{array}{l}\text { Combined } \\
\text { family in- } \\
\text { come per } \\
\text { week }\end{array}$ & $*$ & $*$ & + & $*$ & + & ns & ns \\
\hline $\begin{array}{l}\text { Employment } \\
\text { status }\end{array}$ & $* * *$ & ns & $* *$ & ns & ns & ns & ns \\
\hline
\end{tabular}

People within younger age cohort (25-39), with higher education levels used Internet at home more for purchasing on- line.

People living in Rockhampton, those with youngest cohort (18-24), or those with secondary education level or higher used Internet at home for more for education, when compared to each of their counterparts.

People living in Rockhampton, those within the youngest group, never married or unemployed used Internet at home more for entertainment.

Males, those within the youngest group, with lower family income, and either semi-employed or une mployed used Internet at home more for information search.

Female, those with no children, or those with lower family incomes used Internet at home more for communication through email.

Married people tended to use Internet at home more for financial management.

People within younger age cohort (25-39), with higher education levels tended to use Internet at home more for purchasing on-line. 
Table 15 logistic regressions for each of Internet usage patterns (data were odds ratios with the first category of each factor as a reference)

\begin{tabular}{|c|c|c|c|c|c|c|c|c|}
\hline Parameters & Usage codes & 1 & 2 & 3 & 4 & 5 & 6 & 7 \\
\hline \multirow[t]{2}{*}{ Locations } & Rockhampton & 1.00 & 1.00 & 1.00 & & & & \\
\hline & $\begin{array}{l}\text { Reminder of } \\
\mathrm{CQ}\end{array}$ & 1.49 & 0.51 & 0.69 & & & & \\
\hline \multirow[t]{2}{*}{ Gender } & Male & 1.00 & & & 1.00 & 1.00 & & \\
\hline & Female & 0.63 & & & 0.51 & 1.74 & & \\
\hline \multirow[t]{4}{*}{ Age } & $18-24$ & & 1.00 & 1.00 & 1.00 & & & 1.00 \\
\hline & $25-39$ & & 0.18 & 0.21 & 0.17 & & & 1.99 \\
\hline & $40-55$ & & 0.28 & 0.25 & 0.15 & & & 0.53 \\
\hline & $>55$ & & 0.40 & 0.47 & 0.24 & & & 0.83 \\
\hline \multirow[t]{4}{*}{ Education levels } & Primary & 1.00 & 1.00 & & & & & 1.00 \\
\hline & Secondary & 2.34 & 8.55 & & & & & 2.96 \\
\hline & TAFE & 3.69 & 1.37 & & & & & 2.46 \\
\hline & Uni & 3.49 & 1.45 & & & & & 1.33 \\
\hline \multirow[t]{3}{*}{ Martial status } & Never married & 1.00 & & 1.00 & & & 1.00 & \\
\hline & Used-to-be & 1.03 & & 0.51 & & & 2.11 & \\
\hline & Married & 2.45 & & 0.67 & & & 2.37 & \\
\hline \multirow[t]{2}{*}{ Children at home } & No child & & & & & 1.00 & & \\
\hline & At least one & & & & & 0.50 & & \\
\hline \multirow{3}{*}{$\begin{array}{l}\text { Combined family } \\
\text { income per week }\end{array}$} & $<160$ & 1 & & & 1.00 & 1.00 & & \\
\hline & $160-399$ & 2.25 & & & 0.97 & 0.24 & & \\
\hline & $>400$ & 2.21 & & & 0.21 & 0.69 & & \\
\hline \multirow[t]{3}{*}{$\begin{array}{l}\text { Employment } \\
\text { status }\end{array}$} & $\begin{array}{l}\text { Fully em- } \\
\text { ployed }\end{array}$ & 1.00 & & 1.00 & 1.00 & & & \\
\hline & $\begin{array}{l}\text { Semi- } \\
\text { employed }\end{array}$ & 0.21 & & 0.62 & 2.85 & & & \\
\hline & Unemployed & 0.34 & & 1.30 & 2.89 & & & \\
\hline
\end{tabular}

\section{Research Implications}

It is interesting to note the males in this survey preferred to use Internet for work at home and for information search when compared to their female counterparts who preferred to work away from home, and to use home Internet for communications through email. This finding is consistent with other research. For example, Rovai (2001) found that in distance education via the Internet using the Blackboard.com elearning system, females demonstrated a stronger sense of community than that their male counterparts and that the female students exhibited connected communication patterns while the communication pattern of males was mostly independent.

In this study, people within the youngest group were quite active in home Internet use for education, entertainment and information search, when compared to their elder counterparts. Loges and Jung (2001) also documented significant differences between old and young Americans in Internet access and tendencies in younger groups to pursue a more narrow range of personal goals. Even in developing coun- 
tries, it has also been observed that children seem to understand and use technology fluently without adult intervention (Mitra \& Rana 2001). However, there are growing community concerns that these narrow ranges of Internet usage patterns should be carefully studied and that consuming behaviours should be observed to avoid excessive use and unhealthy use of the Internet (Kraut, R., Patterson, M., Lundmark, V., Kiesler, S., Mukhopadhyay, T., \& Scherlis, W. 1998).

In this study, the youngest group tended to use home Internet for entertainment and on-line search. But the questions of 'how long and how frequently do they use it for entertainment' are not answered. A separate paper by these authors will document the volume and frequency of home Internet usage for all demographic and social economic profiles with a special attention to patterns in young adults. In addition, this study did not collect data on what people searched for in their online information searches. This is an area for future research and it is suggested that the following categories could be examined; education, health care, entertainment (movies, and music), job hunting, weather and news, financial information and personal use. Finally, managing home finance and purchasing on-line have become increasingly popular in recently years and the trends of this growth should be analysed. These authors will also examine this issue in a subsequent paper.

\section{Conclusion}

This paper has identified, presented and discussed the associations between a range of demographic and social economics factors and home Internet use patterns in Central Queensland, Australia. The paper highlights the opportunity for sociologists and physiologists to undertake further research regarding human social and physiological behaviours in home use of the Internet. In addition the paper provides a basis for government agencies and industries to consider these associations in future policy formulation for regional development using ICT.

\section{References}

Chenoweth, L., Stehlik, D. (2002) Using technology in rural practice--Local area coordination in rural Australia. Rural Social Work, University of South Australia 7, 14-21.

Kinnear, P. R., Gray, C. D. (1998) 'SPSS for Windows made simple.' (Psychology Press: Hove UK)

Knote, D., Bohrnstedt, G. W. (1994) 'Statistics for Social Data Analysis.' (F. E. Peacock Publis hers, Inc.: ITASCA, Illionis)

Kraut, R., Patterson, M., Lundmark, V., Kiesler, S., Mukhopadhyay, T., \& Scherlis, W. (1998). Internet Paradox: a social technology that reduces social involvement and psychological well-being? American Psychologist, 53(9), $1017-1031$.

Loges W.E. and Jung J-Y (2001) Exploring the digital divide: Internet connectedness and age. Communication Research 28, 536-562.

Mitra S and Rana V (2001) Children and the Internet: Experiments with minimally invasive education in India. British Journal of Education Technology 32.

Mummery K and Schofield G (2001) 'Central Queensland Social Survey 2001.' Population Research Laboratory, Centre for Social Science Research, Central Queensland University.

NOIE (2002) Regional Australia projects-Overview. In. (The National Office for the Information Economy)

Rovai, A. P. (2001) Building classroom community at a distance: A case study. Education Technology Research \& Development 49, 33-48.

Taylor, W. J. (2002) Factors affecting the adoption of Internet technologies for community practice in a regional area. Doctor of Philosophy thesis, Central Queensland University, Australia.

Taylor, W.J., Zhu, G. X., Dekkers, J. and Marshall, S. (2003) Factors affecting home internet use in Central Queensland. Paper 80 in Proceedings of 2003 Information Science and Information Technology Education Conference Pori Finland 2427 June 2003. 


\section{Biography}

Dr Wal Taylor leads a research effort in Community Informatics Systems (CIS) at the COIN Internet Academy which is a collaborative effort between the Faculty of Informatics and Communication, Central Queensland University, and the Rockhampton City Council. Dr Taylor has a long experience in managing public agency service delivery in regional Australia. He is a part of an international consortium of researchers examining the impact of Internet technologies on civil society and factors affecting ICT adoption for local community benefit. He is particularly interested in CIS relationships between developed and developing countries

Dr Grant X Zhu is a Postdoctoral Research Fellow undertaking research in community informatics for rural regional development in Central Queensland University. He has expertise in rural regional development planning, rangeland management and farming systems management with strong statistical background in both social and natural sciences. Prior to his research program towards his PhD, Dr Zhu's work and training experience geographically covered north western China, Israel and Cameron focusing on rural regional development.

E. Professor John Dekkers has had a successful academic and research career in distance and open learning. He has particular interests in the use of ICT for life long and life wide learning in both developed and developing situations and in the associated research methodologies

Professor Stewart Marshall is the founding Dean of the Faculty of Informatics and Communication at Central Queensland University. He has a wide experience in IT educational processes in academic, community and policy settings in four countries. His Faculty provides undergraduate, graduate and postgraduate teaching and research programs across 14 campuses in eastern Australia and the south western Pacific. Professor Marshall has particular interests in the use of ICT for inclusive educational programs, both in face-to-face and distance education, the changing face of tertiary education in relation to community engagement and community empowerment, particularly in disadvantaged and indigenous communities. 